\title{
ECONOMIC EFFECTS OF DRIED BLUEBERRY PRODUCTION
} \section{EKONOMSKI EFEKTI PROIZVODNJE SUŠENE BOROVNICE}

\author{
Veljko VUKOJE, Ivan PAVKOV, Zoran STAMENKOVIĆ, Aleksandar MILJATOVIĆ \\ Univerzitet u Novom Sadu, Poljoprivredni fakultet, 21000 Novi Sad, Trg Dositeja Obradovića 8, Srbija, \\ e-mail:vukoje@polj.uns.ac.rs
}

\begin{abstract}
This paper analyses various aspects of the cost-effectiveness of dried blueberry production. The drying performed was convective using straw as the main source of heat. A medium capacity dryer was used with a capacity of $400 \mathrm{~kg}$ of fresh blueberries per day, which is suitable for small family farms. The dryer would presumably be in operation for 135 days a year, of which a total of 15 days would be allocated for the drying of US blueberries. In the cost-price structure of dried blueberry production, fresh blueberries predominate as the basic raw material (77.03 \%), followed by packaging costs (12.93\%), labour costs (6.13\%) and energy consumption costs $(1.44 \%)$. Supplanting straw with natural gas, as a much more favourable energy source, does not impede the costeffectiveness of this production. The analysis performed shows that a total of 15 days of effective blueberry drying yields a net profit of $€ 4.040$, which is a very good financial result. Furthermore, the efficiency ratio is 1.28 and the rate of capital accumulation is 22.05 $\%$. The investment costs of dryer construction are not high (about €31,000) and can be covered in less than two years.
\end{abstract}

Key words: dried blueberry, cost, economy, profitability.

\section{REZIME}

U radu se razmatraju različiti aspekti isplativosti proizvodnje sušene borovnice. Koristi se samo konvektivna tehnika sušenja, uz upotrebu slame kao glavnog izvora toplotne energije. Radi se o sušari srednjeg kapaciteta od 400 kg sveže borovnice dnevno, koja je pogodna za izgradnju na manjim porodičnim gazdinstvima. Pretpostavka je da sušara radi 135 dana godišnje, od čega se 15 dana suši američka borovnica. U strukturi cene koštanja dominantno mesto ima sveža borovnica kao osnovna sirovina (77,03\%), zatim slede troškovi pakovanja (12,93\%), rada (6,13\%) i energije (1,44\%). Nizak udeo troškova energije posledica je, prevashodno, upotrebe slame kao glavnog izvora energije, koja je znatno jeftinija od ostalih raspoloživih energenata. Zamena slame prirodnim gasom, kao znatno pogodnijim gorivom, takođe ne ugrožava isplativost proizvodnje. Analiza pokazuje se za 15 dana efektivnog sušenja borovnice ostvaruje neto profit od oko $4.040 €$, što je vrlo dobar finansijski rezultat. Koeficijent ekonomičnosti je 1,28 , a stopa profitabilnosti proizvodnje je 22,05\%. Investicija u podizanje sušare nije velika (oko $31.000 €$ ) i može se otplatiti za period kraći od dve godine. Jasno je da podizanje mini pogona za sušenje voća može predstavljati dobar način za povećanje dohotka porodičnih gazdinstava, uz višetruke pozitivne efekte na povećanje izvoza, razvoj sela i ukupnog agrosektora u Srbiji.

Ključne reči: sušena borovnica, troškovi, ekonomičnost, profitabilnost.

\section{INTRODUCTION}

The blueberry is not a major fruit species in Serbia, but a growing number of producers are taking part in blueberry production on account of its medicinal properties. It is mostly cultivated in Europe and North America. In Serbia, blueberries can be successfully cultivated at an altitude of 300-800 $\mathrm{m}$ and in the southern regions (up to $1000 \mathrm{~m}$ ), although these crops are characterized by high land requirements. Blueberries are successfully grown in deep $(30-50 \mathrm{~cm})$, light and fertile soils with a humus content of 7-10\%, as well as in acidic soils with a pH value of 4.2-4.8 (Blagojević et al., 2012).

The highbush blueberries, known as the American blueberry (Vaccinium corymbosum, lat.), is a perennial plant that starts fruiting in the second year and matures to full fertility within six to seven years. The period of exploitation of this seedling is up to 50 years (www.poljoberza.net). Diseases and pests are major hindrances in blueberry production, birds in particular, causing great damage to blueberry plantations. Weather extremes (freezing rain) can also cause serious damage to the crops, thus netting protection is of paramount importance (https://agroekonomija.wordpress.com).

In Serbia, the blueberry matures from the end of June to the middle of August and, in higher regions, the beginning of September. Fresh blueberries must be calibrated and classified into two categories. Fruits can be stored from 1 to 3 days (at a temperature of $12-15{ }^{\circ} \mathrm{C}$ ), from 3 to 4 weeks (at a temperature 2-
$4{ }^{\circ} \mathrm{C}$ ), and 3 to 4 months in specialized refrigerators with a controlled atmosphere. Blueberries can be processed into various types of juices, concentrates, compotes, jams, and others products. Highly valued and expensive wines, as well as strong alcoholic beverages are made from blueberries.

The production of blueberries is constantly increasing in the world. In recent years, a rapid increase in the production of blueberries has also been recorded in Serbia, with an area of approximately 900 ha devoted to blueberries. This can be accounted for by a relatively high and stable selling price of fresh blueberries. Under favourable natural conditions and using the proper production technology, an average yield of approximately $15 \mathrm{t} / \mathrm{ha}$ can be obtained. Conversely, the investment requirements of this production are not negligible and range from 30,000 to 50,000 euros per hectare.

Dried blueberries have been receiving increased attention because of their medicinal properties and the consumers' need for healthy foods. One method of drying blueberries is vacuum drying, which entails drying fruit at a lower temperature than at atmospheric pressure. The advantages of this method are the low temperature and removal of over $90 \%$ of the present water, which ensures the maximum preservation of thermally sensitive and biologically active substances. The nutritional value of the dried product is slightly changed in relation to the nutritional value of the fresh raw material. A relatively complex design of a vacuum dryer, with a 
limited capacity, is a major disadvantage of vacuum drying (̌̌umić, 2014).

As high-technology products have a higher added value, they generate greater profits. Therefore, it is necessary to pay more attention to all types of fruit processing, especially those that are less developed such as fruit drying.

Dried fruits are becoming an increasingly important product, which, in addition to low consumption in the domestic market, are gradually becoming an export commodity. Fruit drying, with the exception of plums, is at a low level in our country (Milić et al., 2006). The Republic of Serbia has significant capacities for dried fruit production, which are only partially used (Lukač-Bulatović et al, 2013). The blueberry is dried in relatively modest quantities in Serbia, and the use of conventional drying methods is almost nonexistent. The research conducted at the Faculty of Agriculture, the University of Novi Sad, has shown that the blueberry can be successfully dried using the conventional convective drying process. The crucial issue raised is, of course, the profitability of dried blueberry production. The primary purpose of this paper is to determine and evaluate the most important profitability indicators of dried blueberry production.

\section{MATERIAL AND METHOD}

Blueberries can be dried using various technological procedures and solutions. Pavkov et al. (2017) successfully dried blueberries using conventional technology. The technique consisted of blueberry pebbling, washing, laying on the wood, drying, and rehydrating before packaging. The drying process was carried out at a temperature of $70^{\circ} \mathrm{C}$ and an air velocity of $1.5 \mathrm{~m} / \mathrm{s}$. The experiment was performed in a convective experimental dryer IVA 2 at the Faculty of Agriculture, the University of Novi Sad. The dryer was equipped with devices for measuring and controlling the most important parameters during the drying process such as the air temperature and mass of the samples on the wood. Temperature and mass sensors were connected to a computer, which allowed the collection of measured data during the drying period. Blueberries were purchased from a manufacturer in Bačka Topola. The initial humidity was $82 \%$ (relative to the wet basis), and dried to a humidity-safe storage of $20 \%$. The drying time was $10 \mathrm{~h}$. The product for sale was rehydrated using a water solution and glucose-fructose syrup concentration of $5 \%$ at a temperature of $80{ }^{\circ} \mathrm{C}$ for 3 minutes. After rehydration, the moisture content was $24 \%$.

Based on the established technical and technological parameters, an economic analysis of the cost-effectiveness of dried blueberry production was carried out. The research involved a medium capacity plant suitable for family farm production. Only technological phases of preparation, drying and packaging were considered. The analysis was based on the following production, technological and economic assumptions:

- drying capacity of $400 \mathrm{~kg}$ of fresh blueberries per day, i.e. 96.6 $\mathrm{kg}$ of dried blueberries; the work hours entail two shifts and a total of 4 workers, one of whom is familiar with the production technology;

- dryer is effectively used for 135 days a year, out of which 15 days are allocated for blueberry drying $(6,000 \mathrm{~kg}$ fresh, or $1,450 \mathrm{~kg}$ of dried blueberries in total); other fruits are dried in the remaining 120 days (cherry, peach, apricot, apple, pear and quince);

- calculations are based on the laboratory standards for materials, labour and energy, i.e. according to the following mass balance: $73.84 \%$ of fresh blueberries are waste on evaporated water, usable waste makes $2.0 \%$, and $24.16 \%$ remains as dry blueberry;
- fresh blueberries are bought on the market, the farm has its own mini refrigerators, and the profitability rate using selfproduced blueberries is also considered;

- costs and value of production are based on the real market prices from the second half of 2017, i.e. on the average exchange rate of the euro in the period under consideration ( $€$ 1= RSD 120); all prices are expressed without VAT;

- for dryer establishment (i.e. equipment and accessories, construction of facilities, including a mini refrigerator), total investments of around $€ 31,000$ are required; if there is an appropriate facility in an economic yard that can be adapted, the investments could be considerably reduced (Vukoje and Milić, 2011).

The analysis of economic indicators in the production of dried blueberries is primarily based on the analytical calculation of costs and results. In addition, for the purpose of detailed calculation and a clearer display of costs and results, the calculation according to technological operations (material preparation, convective drying, rehydration, packaging and distribution) is used. Direct costs are primarily calculated for daily production, and then, based on the average euro exchange rate, calculations are made for the 15-day production of dried blueberries. For general costs, the procedure is reversed, determined annually, and then divided by 135 days of effective operation of the dryer to obtain the daily amount. For a reliable estimate of the cost-effectiveness of blueberry drying, it is also necessary to determine additional indicators of success (margin of coverage, income, investment return time, efficiency coefficients and production accumulation). The movement of net results relative to the change in the market prices of fresh and dried raspberries is also considered.

\section{RESULTS AND DISCUSSION}

When used in a normal exploitation capacity of about 400 $\mathrm{kg} /$ day of fresh blueberries, the observed dryer requires daily costs in an amount of RSD 111,424, or $€ 13,928$ for 15 days of drying (Table 1). In the total cost structure of dried blueberries, fresh blueberries dominate as the basic raw material (77.03\%). It is expected that the costs of fresh blueberries exerts the crucial impact on the cost price of dried blueberry production, i.e. the profitability of dried blueberry production.

Packaging costs are also relatively significant (12.93\%) given that smaller packages are planned for up to 100 grams. Labour costs participate with $6.13 \%$, whereas the share of energy costs is very modest (1.44\%). Extremely low energy costs are the result of the use of straw as a primary energy source, which is considerably cheaper than other available fuels, as well as low electricity prices in Serbia. It has been confirmed once again that energy costs are not crucial for the costeffectiveness of dried fruit production, although such misconceptions can often be heard. This does not mean that energy costs are not important for raising the profitability of dried fruit production, but only that, under specific market conditions, they do not constitute a key element of the price cost.

Under such circumstances, the issue of supplanting straw with natural gas, which is considered more favourable from a technological and organizational perspective, is also logically raised. In this instance, the equivalent quantity of natural gas is $96.5 \mathrm{~m}^{3} /$ day, which at a price of $39.5 \mathrm{din} / \mathrm{m}^{3}$ increases the costs of energy in the production of dried blueberries for $289.1 € / 15$ days. The share of energy costs remains at a relatively low level of $2.23 \%$, and the profit is reduced by around $925 € / 15$ days. Therefore, the cost-effectiveness of dried blueberry production is still not at stake, and certainly deserves serious consideration under the present production conditions. Considering the low 
Table 1. Production calculation of dried blueberries $(€ 1=$ RSD 120)

\begin{tabular}{|c|c|c|c|c|c|c|c|}
\hline \multicolumn{8}{|c|}{ Dryer capacity: $\mathbf{4 0 0} \mathrm{kg}$ of fresh blueberry per day, or $\mathbf{6 0 0 0} \mathrm{kg}$ in 15 days } \\
\hline No. & TEHNOLOGICAL OPERATION & Unit & Quantity & Price & RSD/per 1 day & $€ /$ per 15 & days \\
\hline 1 & Fresh blueberry & $\mathrm{kg}$ & 400.0 & 220.0 & $88,000.0$ & & $11,000.0$ \\
\hline 2 & Water & l & $1,000.0$ & 0.13 & 130.0 & & 16.3 \\
\hline 3 & Labour costs & $\mathrm{h}$ & 16.0 & 175.0 & $2,800.0$ & & 350.0 \\
\hline $\mathbf{I}$ & \multicolumn{4}{|l|}{ Preparation of drying material } & $90,930.0$ & & $11,366.3$ \\
\hline 4 & Electrical energy & kwh & 16.0 & 8.1 & 129.6 & & 16.2 \\
\hline 5 & Heat energy (straw) & $\mathrm{kg}$ & 250.0 & 5.6 & $1,388.9$ & & 173.6 \\
\hline 6 & Labour costs & $\mathrm{h}$ & 16.0 & 175.0 & $2,800.0$ & & 350.0 \\
\hline II & \multicolumn{4}{|l|}{ Convective drying } & $4,318.5$ & & 539.8 \\
\hline 7 & Electrical energy & kwh & 16.0 & 8.1 & 129.6 & & 16.2 \\
\hline 8 & Bimbon syrup & $\mathrm{kg}$ & 2.0 & 75.0 & 150.0 & & 18.8 \\
\hline 9 & Labour costs & $\mathrm{h}$ & 4.0 & 175.0 & 700.0 & & 87.5 \\
\hline III & \multicolumn{4}{|l|}{ Reduction } & 979.6 & & 122.5 \\
\hline 10 & Packaging & & & & $14,496.2$ & & $1,812.0$ \\
\hline 11 & Labour costs & $\mathrm{h}$ & 4.0 & 175.0 & 700.0 & & 87.5 \\
\hline IV & \multicolumn{4}{|l|}{ Finalization } & $15,196.2$ & & $1,899.5$ \\
\hline A ) & \multicolumn{4}{|l|}{ VARIABLE COSTS (1 to 11) } & $111,424.3$ & & $13,928.0$ \\
\hline 12 & \multicolumn{4}{|l|}{ Depreciation and maintenance } & $1.808,7$ & & 226.1 \\
\hline 13 & \multicolumn{4}{|l|}{ General costs and interest } & $1,010.0$ & & 126.3 \\
\hline \multirow[t]{3}{*}{ В) } & \multicolumn{4}{|l|}{ TOTAL COSTS (1 do 13) } & $114,243.0$ & & $14,280.4$ \\
\hline & \multirow{2}{*}{ ACHIEVED RESULTS } & \multirow{2}{*}{ Unit } & \multirow{2}{*}{ Quantity } & \multirow{2}{*}{ Price } & \multirow{2}{*}{ RSD / for 1 day } & \multicolumn{2}{|c|}{ COST PRICE } \\
\hline & & & & & & $\mathrm{RSD} / \mathrm{kg}$ & $€ / \mathrm{kg}$ \\
\hline 14 & Dried blueberries & $\mathrm{kg}$ & 96.6 & $1,510.0$ & $145,926.0$ & $1,175.5$ & 9.8 \\
\hline 15 & Side product & $\mathrm{kg}$ & 8.0 & 80.0 & 640.0 & 80.0 & 0.7 \\
\hline C) & \multicolumn{4}{|l|}{ VALUE OF PRODUCTION (14 + 15) } & $146,566.0$ & \multicolumn{2}{|r|}{$18,320.8$} \\
\hline D) & \multicolumn{4}{|l|}{ PROFIT (C - B) } & $32,323.0$ & & $4,040.4$ \\
\hline
\end{tabular}

electricity consumption, it means that not even a significant increase in the price of this energy, which can be expected in the future, can significantly affect the profitability of dried blueberry production.

Fixed costs account for a modest $2.47 \%$ of the total cost of dried blueberries (depreciation and amortization equates to 1.58 $\%$, general costs and interest equate to $0.88 \%$ ). The general costs mainly include the overheads of the farm (telephone, fuel and travel expenses, insurance, taxes and property contributions, administrative services, eventual sales costs, etc.), of course, their proportionate part for a 15-day production of dried blueberries.

The price of dried blueberry is $1,175.5 \mathrm{RSD} / \mathrm{kg}(9,80 € / \mathrm{kg})$, wholesale price is $1,510.0 \mathrm{RSD} / \mathrm{kg}$. When VAT is charged at this price $(20 \%)$ and the average trade margin (20\%), the retail price of dried blueberry is $3,600 \mathrm{RSD} / \mathrm{kg}(18,12 € / \mathrm{kg})$. This is a very competitive price of dried blueberry both in the domestic market and for export. Given that this is a relatively new and poorly represented product in the domestic market, in the future, it may be possible to achieve a higher selling price. Usable waste can be used to produce alcohol distillation.

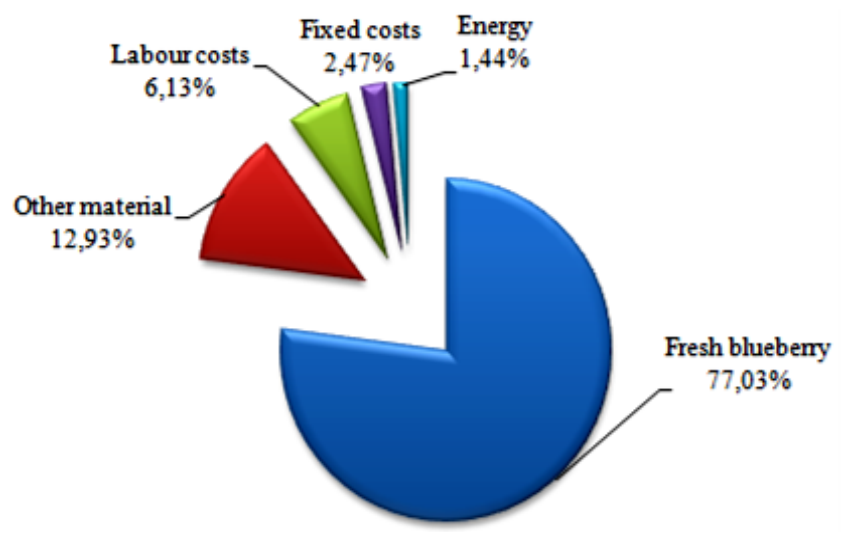

Fig. 1. Cost structure of dried blueberry production (\%)

The analysis shows that, for 15 days of effective drying of blueberries, a profit of about RSD 32,323 (€ 4,040) is realized, which can be considered as a very good result. In addition, the rate of capital accumulation (22,05\%) and the efficiency ratio (1.28) are also at a relatively high level (Table 2). If 2 household 
members are involved in the production of dried raspberries then the profit can be expressed as "income" of the farm, which amounts to 4,478 €/15 days. Eventually, using fresh blueberries from their own production would significantly reduce production costs and increase the financial result, as the calculation would be based on the cost price.

Table 2. Additional indicators of success

\begin{tabular}{|c|c|c|c|}
\hline No & Position & RSD/for 15 days & $\begin{array}{c}\text { €/for } 15 \\
\text { days }\end{array}$ \\
\hline 1 & $\begin{array}{c}\text { Margin of coverage } \\
(\mathrm{C}-\mathrm{A})^{*}\end{array}$ & $35,141.7$ & 4,392.7 \\
\hline 2 & $\begin{array}{l}\text { Household income } \\
\text { (D+1/2 Earnings)** }\end{array}$ & $35,823.0$ & $4,477.9$ \\
\hline 3 & $\begin{array}{l}\text { The coefficient of } \\
\text { economy (C / B) }\end{array}$ & 1.28 & \\
\hline 4 & $\begin{array}{c}\text { Accumulation of } \\
\text { production (D / C) }\end{array}$ & $22.05 \%$ & \\
\hline
\end{tabular}

* Labels in parentheses refer to the positions in Table 1.

* The assumption is that two members of the household are employed.

The sensitivity analysis shows that the production of dried blueberries can bear significant price changes of basic inputs and finished products. The financial result becomes negative only with the increase in the market price of fresh blueberries by 37 $\%(301 \mathrm{RSD} / \mathrm{kg})$ at the unchanged price of dried blueberries. Profitability is considerably more sensitive to the variation in the market price of the finished product, as it already gets a negative sign when it is reduced by $23 \%(1,163 \mathrm{RSD} / \mathrm{kg})$.

During the year, dryers are in operation for 135 days, which means that other fruit types of different levels of profitability are also dried. Therefore, reliable estimates of the cost-effectiveness of the construction and use of fruit drying plants can be carried out only by including the analysis of all dried fruit production that are represented during the year. In this case, such estimates of dried blueberry production cost-effectiveness are possible as there are research results for other types of fruit that were previously published in the framework of this project (Vukoje

Table 3. Analysis of the cost-effectiveness of dried fruit production

\begin{tabular}{|c|c|c|c|c|c|}
\hline No. & Production & $\begin{array}{c}\text { Number of } \\
\text { days of drying }\end{array}$ & Profit (€) & $\begin{array}{c}\text { Economics } \\
\text { coef. }\end{array}$ & $\begin{array}{c}\text { Profit } \\
\text { (€/for } 1 \text { day })\end{array}$ \\
\hline 1 & Apricot & 20 & 3,191.2 & 1.49 & 159.6 \\
\hline 2 & Apple & 25 & $3,861.3$ & 1.58 & 154.4 \\
\hline 3 & Cherry & 15 & $3,188.7$ & 1.50 & 212.6 \\
\hline 4 & Peach & 15 & $1,377.9$ & 1.29 & 91.9 \\
\hline 5 & Pear & 15 & $1,725.0$ & 1.40 & 115.0 \\
\hline 6 & Quince & 15 & $1,635.9$ & 1.30 & 109.1 \\
\hline 7 & Raspberry & 15 & $6,210.0$ & 1.41 & 414.0 \\
\hline 8 & Blueberry & 15 & $4,040.4$ & 1.28 & 269.4 \\
\hline 9 & TOTAL & 135 & $25,230.4$ & & \\
\hline 10 & \multicolumn{2}{|c|}{ Total profit reduced by $10 \%$ of tax } & $22,707.4$ & & \\
\hline 11 & \multicolumn{2}{|c|}{ Depreciation on an annual basis } & $1,734.9$ & & \\
\hline 12 & \multicolumn{2}{|c|}{ All inflows $(10+11)$} & $24,442.2$ & & \\
\hline 13 & \multicolumn{2}{|c|}{ Total investment value $(€)$} & $31,000.0$ & & \\
\hline 14 & \multicolumn{2}{|c|}{$\begin{array}{l}\text { Time of return on investment } \\
\qquad(13 / 12)\end{array}$} & 1.27 & & \\
\hline
\end{tabular}

and Pavkov, 2015; Vukoje et al., 2011; 2013; 2017). With the assumed production structure, according to the types of fruits dried during the year, a total profit of $€ 25,230$ is realized in 135 days of effective drying operation (Table 3 ).

The return on investment is one of the most important indicators of the justification for an investment. In the present case, the investment is covered in 1.27 years, which represents a very short repayment period for every type of investment.

For analysis, it is important to compare the level of profitability of the production of different types of dried fruit as this can serve as a basis for planning the production structure in the future period. In doing so, it is best to use the following relative indicators of success: the efficiency ratio, the rate of capital accumulation, and the amount of profit per one day of production (Table 3). According to the efficiency ratio (production and cost ratio), the production of dried apples is most cost-effective is (coefficient 1.6), followed by sour cherry (1.50) and apricot (1.49), whereas the production of dried blueberries has the lowest efficiency ratio (1.28). The rate of capital accumulation shows the identical order of profitability of individual production as the cost-effectiveness, which is logical since it is a similar type of indicator (profit ratio and production value, which are not shown in the table). The order of profitability, however, is significantly different if one considers the amount of profit generated after one day of production. The biggest daily profit is generated in the drying of raspberries (€414.0), blueberries (€269.4) and cherries (€212.6), whereas the minimum daily gain in dried peach production (€91.9). Previous comparisons should be taken with reserve, given the significant fluctuations in input prices, finished products prices, as well as the euro exchange rate, in some years.

Given that different criteria show contradictory results, the issue of criteria prioritization arises. On balance, one should take into account what constitutes the strongest limiting factor of production or total profit maximization. For example, if the constrain is the financial resources that the farm has at its disposal then the most important indicator is the efficiency ratio because one RSD of investment makes the largest profit. In contrast, if the farm has no restrictions on financing the production and the number of days of effective operation of the dryer during the year, priority should be given to those products which reject the highest earnings per day as the overall profit will be the highest. In addition, other constraints, and above all the possibility of placement of individual products, and the availability of the basic raw material (total quantity and uniformity during the year), that is, the possibility of storing raw materials and finished products, should be taken into account.

\section{CONCLUSION}

The production and consumption of dried fruit is constantly increasing in the world. The dried fruit production in the Republic of Serbia is relatively modest, with the exception of dried plums. The production of dried 
blueberries almost does not exist, or it is in embryo. An analysis of the most important economic parameters shows that drying blueberries can be a very profitable business. For 15 days of effective production, a profit of $€ 4,040$ is generated, with an efficiency ratio of 1.28 and a rate of capital accumulation of $22.05 \%$. Even a significant increase in the price of basic inputs cannot exert an adverse effect on the cost of blueberry drying. Relatively modest initial investments of around $€ 31,000$ are covered in about 1.27 years. By hiring family members, an additional household profit of about 3,700 €/year can be generated.

It is necessary to undertake a series of measures to utilize respectable natural, technical and technological potentials to raise the production of dried fruit to a significantly higher level. There are particularly great opportunities for the export of quality dried fruit, both in the countries of the region and in the more developed world markets. For successful international marketing, the following measures should be implemented: good preparation and selection of appropriate fruit drying varieties, the adoption and application of international production standards, quality control, packaging and logistics, the appropriate marketing strategy, disseminating the knowledge about fresh and dried fruit production, more accessible sources of financing, additional incentives for the construction of dryers, etc.

ACKNOWLEDGEMENTS: This paper is a result of the project TR31058, supported by the Ministry of Education, Science and Technology of the Republic of Serbia.

\section{REFERENCES}

Agroekonomija:https://agroekonomija.wordpress.com/2010/12/18/org anska-produkcija-borovnice (date of acces: Februar, 2018).

Blagojević, R., Filipović, N., Božić, V. (2012). Nega, berba i prerada šumskog voća. Kancelarija za program podrške u privatnom sektoru za podršku sektoru voćarstva i bobičastog voća u Južnoj Srbiji, Niš.

Lukač-Bulatović, Mirjana, Rajić, Z., Đoković, Jelena (2013). Development of fruit production and processing in the
Republic of Serbia, Economics of Agriculture, 60 (1), 141151.

Milić, D., Lukač-Bulatović Mirjana, Kukić, Đ. (2006. Mogućnosti proizvodnje sušenog voća u Srbiji, Časopis za procesnu tehniku i energetiku u poljoprivredi / PTEP, 10( 1-2), str. 23-25

Pavkov, I., Radojčin, M., Stamenković, Z., Kešelj, K., Bikić, S., Mitrevski, V., Ponjičan, O (2017): Convective and freeze drying of raspberry: effect of experimental parameters on drying kinetics, physical properties and rehydration capacity, Proceedings - The Third International Symposium on Agricultural Engineering ISAE-2017, Faculty of Agriculture, University of Belgrade, Belgrade, Serbia, No. 3, pp. 19 - 29.

Poljoberza: http://www.poljoberza.net/PG20_6.aspx (date of acces: februar, 2018).

Republički zavod za statistiku Srbije: http://webrzs.stat.gov.rs (date of acces: decembar, 2018).

Šumić, Z. (2014). Optimizacija sušenja voća u vakuumu. Doktorska disertacija, Tehnološki fakultet, Novi Sad, Srbija.

Vukoje, V., Milić, D. (2011). Analiza ekonomske opravdanosti proizvodnje sušenog voća u Srbiji. Agroznanje, 12 (1), 5-14, Poljoprivredni fakultet Banja Luka.

Vukoje, V., Milić, D., Pavkov, I. (2011). Production-Economic Parameters of Dried Quince. Proceedings of the XXII Internacional Symposium Food safety production, Poljoprivredni fakultet, Novi Sad, pp. 227-230.

Vukoje, V, Živković, Jasmina, Zekić, V., Matković, M. (2013). Economic effects of dried sour cherry production in Serbia. Proceedings of the IV International Agronomic Symposium „Agrosym 2013“, Jahorina, Bosnia and Herzegovina, 3-6. October, pp. 792-795.

Vukoje, V., \& Pavkov, I. (2015). Profitability of dired apple production in Serbia. Contemporary Agriculture, 64(3-4), 143149.

Vukoje, V., Radojčin, M., Dulić, Vesna (2017). Cost-effectiveness assessment of dried raspberry production, Journal on Processing and Energy in Agriculture (PTEP), 21 (1), 50-52.

Received: 27. 03. 2018.

Accepted: 21. 08. 2018. 